\title{
CREEPING (SECONDARYITERTIARY SETTLEMENTS) OF HIGHLY COMPRESSIBLE SOILS AND SLUDGE
}

\author{
TEČENJA (SEKUNDARNA/TERCIJALNA SLEGANJA) VEOMA STIŠLJIVOG \\ TLA I TALOGA
}

\section{H. BRANDL}

\section{GENERAL}

K. Terzaghi and O.K. Fröhlich's theory of (one dimensional) consolidation refers to the dissipation of excess pore water pressure during loading of saturated soil. The time taken for the clay to consolidate depends entirely on the permeability of the laterally confined clay. These assumptions correspond to the primary consolidation in an oedometer test (widely neglecting possible rearrangements of the soil structure already in the initial phase of loading).

At the 1st International Conference on Soil Mechanics and Foundation Engineering 1936 at Harvard University, Cambridge, MA., A.S. KeverlingBuisman presented a theory for creep of fine-grained soft soils. However, this (logarithmic) formula and his statement that creeping of clays never ends was severely questioned, not only by K. Terzaghi (Conference Chairman), but also internationally. Meanwhile this theory has been accepted theoretically and could be widely confirmed, especially by the following test results showing low-term creep, but also a fading out tertiary creep.

\section{SETTLEMENT I CREEPING OF HIGHLY COMPRESSIBLE (ORGANIC) CLAYEY SILT}

Total settlement of saturated cohesive soil comprises immediate settlements ( $s_{o}$ - undrained, at constant volume), primary settlements $\left(\mathrm{s}_{1}\right.$ - consolidated by pore water pres-
ORIGINALNI NAUČNI RAD ORIGINAL SCIENTIFIC PAPER

UDK: 624.131 .542

doi:10.5937/GRMK1801027B pressure dissipation) and long-term creeping $\left(\mathrm{s}_{2}, \mathrm{~s}_{3}\right)$. In the field, all phases interact during transition zones, and creeping under shear stress also occurs. This leads inevitably to soil rheology comprising also cohesionless soils and other geomaterials.

In the design phase (1971 - 1972) of a highway junction on highly compressible soils with locally organic inclusions and peaty interlayers numerous samples were taken and investigated in the laboratory. Several of them were left in the oedometers for long-term creeping tests. The maximum observation period has been from 1971 to 2013, hence 42 years. Some results are described in the following, further investigations and in-situ influences of ground improvement measures are given in the chapter after next.

Table 1 shows the relevant data of a selected sample (A). It is an extremely soft clayey silt $(33 \%<0,002 \mathrm{~mm})$ with organic components of liquid consistency. The plasticity index of $I_{p}=0.34$ is rather due to the decomposed peaty organics than to the mineralogical composition of the fines as can be seen from Table 2. The platy shape of the fines and its way of sedimentation created a special fabric and high compressibility.

In the natural state the permeability coefficient was about $k=10^{-7} \mathrm{~m} / \mathrm{s}$ but dropped significantly during loading. At the maximum load finally a value of about $k=10^{-9} \mathrm{~m} / \mathrm{s}$ was reached. These data explain, among other influence factors, the relatively quick primary consolidation and a long-lasting creeping phase.

BRANDL, H. Emeritus Professor, Vienna University of Technology 
Table 1.Geotechnical parameters of organic soil (sample A) and pre-treated sewage sludge (samples B, C). In brackets the years of test start.

\begin{tabular}{|c|c|c|c|c|}
\hline & & $\begin{array}{c}\text { Sample A } \\
(1971)\end{array}$ & $\begin{array}{c}\text { Sample B } \\
(1997)\end{array}$ & $\begin{array}{c}\text { Sample C } \\
(2003)\end{array}$ \\
\hline Natural water content & $w_{n}(\%)$ & 130 & 168 & 131 \\
\hline Unit weight of soil particles & $\gamma_{s}\left(\mathrm{kN} / \mathrm{m}^{3}\right)$ & 2.52 & 2.32 & 2.21 \\
\hline Voidratio & $e(-)$ & 4,68 & 4.06 & 3.17 \\
\hline Initial dry density & $V_{d}\left(\mathrm{kN} / \mathrm{m}^{3}\right)$ & 0.44 & 0.46 & 0.50 \\
\hline Liquid limit & $w_{l}(\%)$ & 92 & 84 & \multirow{3}{*}{$\begin{array}{c}\text { Test } \\
\text { not possible }\end{array}$} \\
\hline Plasticitylimit & $w_{p}(\%)$ & 58 & 72 & \\
\hline Plasticityindex & $I_{p}(\%)$ & 32 & 12 & \\
\hline Ignitionloss & $(\%)$ & 25 & 35 & 27 \\
\hline
\end{tabular}

Table 2. Mineralogical contents of the organic clayey silt (sample A)

\begin{tabular}{|l|c|}
\hline Mica-group & $33 \%$ \\
\hline Chlorite-group & $16 \%$ \\
\hline Quartz & $40 \%$ \\
\hline Feldspar (mainly plagioclase) & $11 \%$ \\
\hline
\end{tabular}

Figures 1, 2 show the void ratio - pressure diagram and the time-settlement curves of the particular load steps. The sample was kept under water to simulate in situ conditions and to prevent settlements by shrinking, Figure 2 illustrates that secondary creep occurred linearly with the logarithm of time until about one year, followed by a transition period to tertiary creep which gradually leads to a fading out of the settlement. Such a behaviour coincides with site observations showing a decreasing gradient of long-term creeping plotted on semi-logarithmic scales. This coefficient was normally considered to be constant. However, even after 42 years no final value has been reached in the oedometer test, thus indicating viscous behaviour and on-going rearrangements of the soil micro-structure, due to tabular sheet silicate in connection with the loss of adhesive water, and microscopic interactions between particles and liquid. Moreover, the compression curve partly consists of segments mutually intersecting in bifurcation points which mark occasional structural collapses. This is schematically indicated in the enlarged detail within Fig. 2.

The oedometer tests were performed with incremental loading, also comprising hydraulic conductivity tests with falling height. The sample height was $\mathrm{h}=20 \mathrm{~mm}$, the diameter varied between $d=60$ to $100 \mathrm{~mm}$, hence providing a d:h ratio of 3 to 5 (to assess possible skin friction).

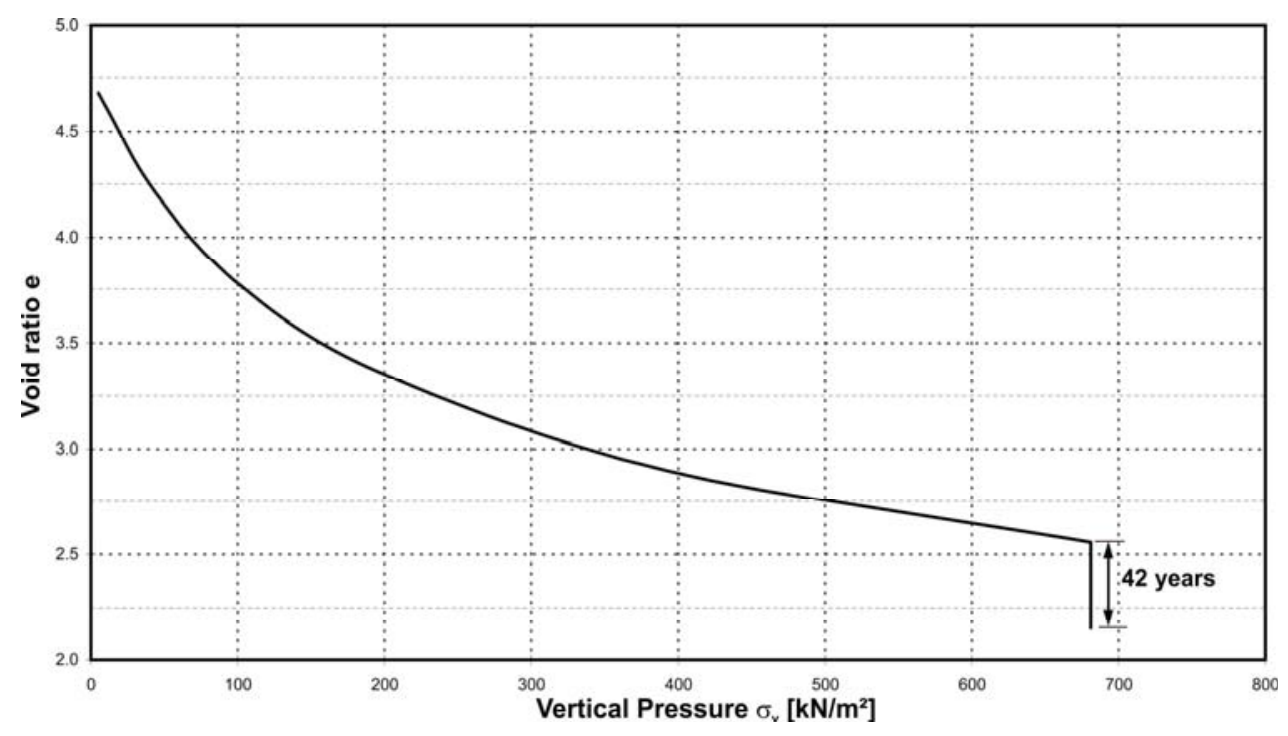

Figure 1. Void ratio - pressure diagram (oedometer test) for organic clayey silt (sample A) 


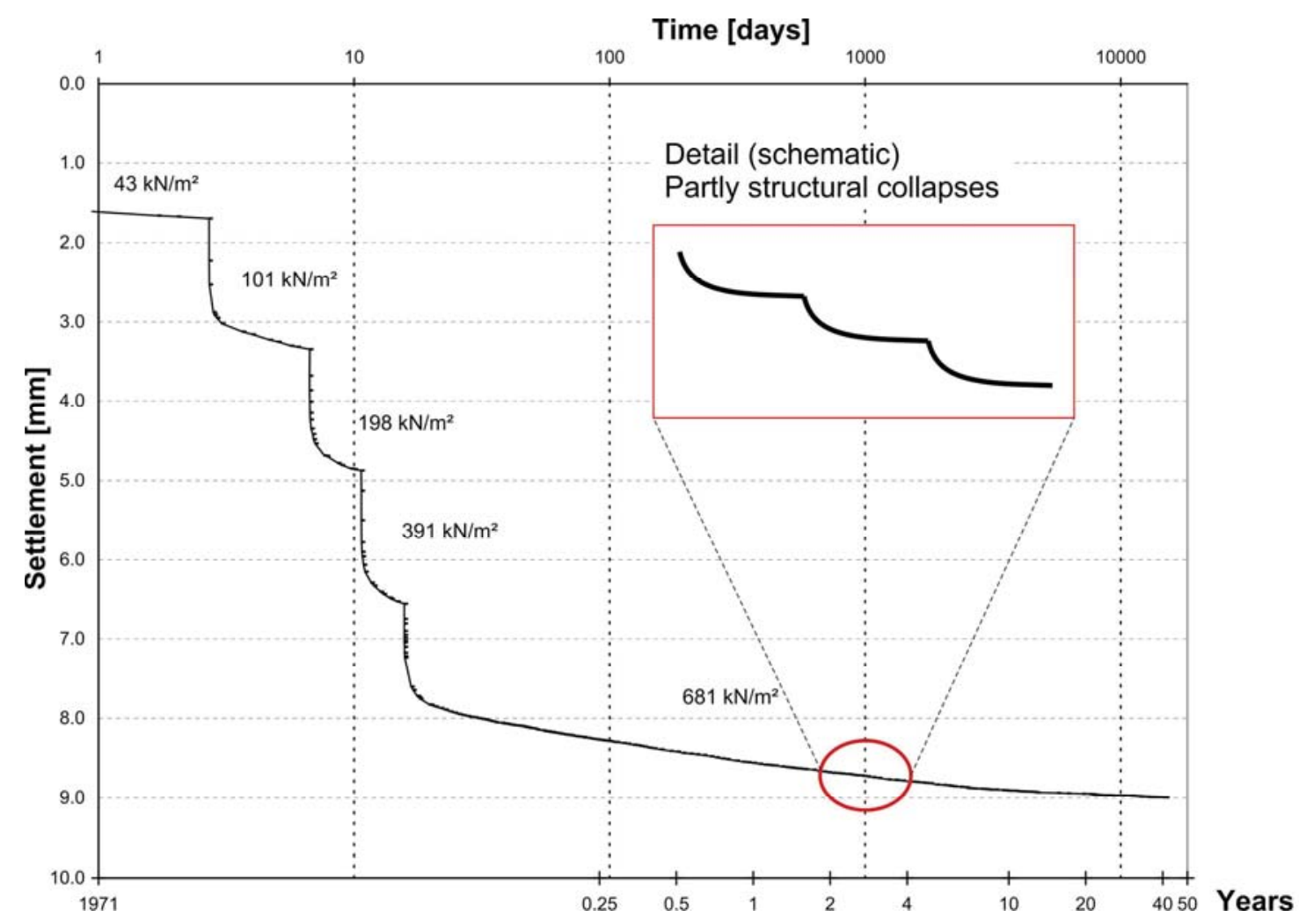

Figure 2. Settlement - log time curve for sample A. Load steps $\left(\sigma_{v}\right)$ and maximum load during 42 years. Also indicated are occasional structural collapses.

\section{LONG-TERM SETTLEMENT OF PRE-TREATED SEWAGE SLUDGE}

During the past decades ponds, pit landfills or surface impoundments of liquid sewage sludge have been increasingly substituted by waste deposits of pretreated sewage sludge, unless this is not incinerated. Such landfills may reach a height of $30 \mathrm{~m}$ and more, thus requiring stability analyses, settlement prognoses, assessment of long-term behaviour of the liners, etc. Consequently, these aspects have become a special field of geotechnical engineering.

Suitability tests, starting in the early 1990s disclosed that sewage sludge dewatered in a filter press and stabilized with unslaked lime can be easily deposited in all kinds of waste disposal facilities.

After comparative test series at the filter press and on the landfill with 20 to $45 \% \mathrm{CaO}$, an amount of about $31 \%$ was found to be optimal. Furthermore, 5 to $7 \%$ $\mathrm{FeCl}_{3}$ was added as aflocculant. In the case of sample $\mathrm{B}$ $22 \% \mathrm{CaO}$ was added (referring to the dry mass), in the case of sample C $31 \% \mathrm{CaO}$. When reacting with water, $\mathrm{Ca}(\mathrm{OH})_{2}$ developed, thus creating a highly basic environment. Depending on the untreated sludge properties the hydraulic conductivity first decreased with the amount of added $\mathrm{CaO}$ but then increased. However, in the long-term decreasing k-values could be observed also for high $\mathrm{CaO}$ addition. This is rather similar to the stabilization of fine soils with lime.

Samples from the undisturbed filter-cake exhibited hydraulic permeability coefficients of only $k=10^{-9}$ to 10

${ }_{10} \mathrm{~m} / \mathrm{s}$. However, after field compaction of the broken filter cake these values increased to an in-situ permeability of about $\mathrm{k}=10^{-7}$ to $10^{-8} \mathrm{~m} / \mathrm{s}$, though the dry density was only $\rho_{d}=0.45$ to $0.55 \mathrm{~g} / \mathrm{cm}^{3}$ (water content usually about $\mathrm{w}=130 \%)$. In the long-term in-situ values down to $\mathrm{k}=10^{-9}-10^{-10} \mathrm{~m} / \mathrm{s}$ were measured, depending on the amount of added lime.

The k-value decreased with time due to mechanical, chemo-physical and biological long-term reactions. In the laboratory, values of $\mathrm{k}=5.10^{-7}$ to $10^{-9} \mathrm{~m} / \mathrm{s}$ were measured within six months of curing, depending on vertical load and $\mathrm{CaO}$ additives. Figure 3 shows an example of long-term tests (running 16 years) together with the scatter of several test series with 25 to $35 \%$ $\mathrm{CaO}$ within the first two years at a vertical pressure of $250 \mathrm{kN} / \mathrm{m}^{2}$. Hence, pre-treated stabilized sludge can be thoroughly considered as secondary barrier material within the sealing system of a waste deposit. However, compaction in layers is essential.

In order to investigate the long-term behaviour of pre-treated sewage sludge and to find analogies between sludge and soil behaviour several samples were taken. The focus has been on creeping because this has the largest influence on the long-term behaviour of the surface liner of a waste deposit with regard to (differential) settlements.

In the following two examples are selected including long-term oedometer tests running from 1997 and 2003 respectively, until 2013 . The samples were always under water and exposed to a constant temperature of $20^{\circ} \mathrm{C}( \pm$ $\left.1{ }^{\circ} \mathrm{C}\right)$. 


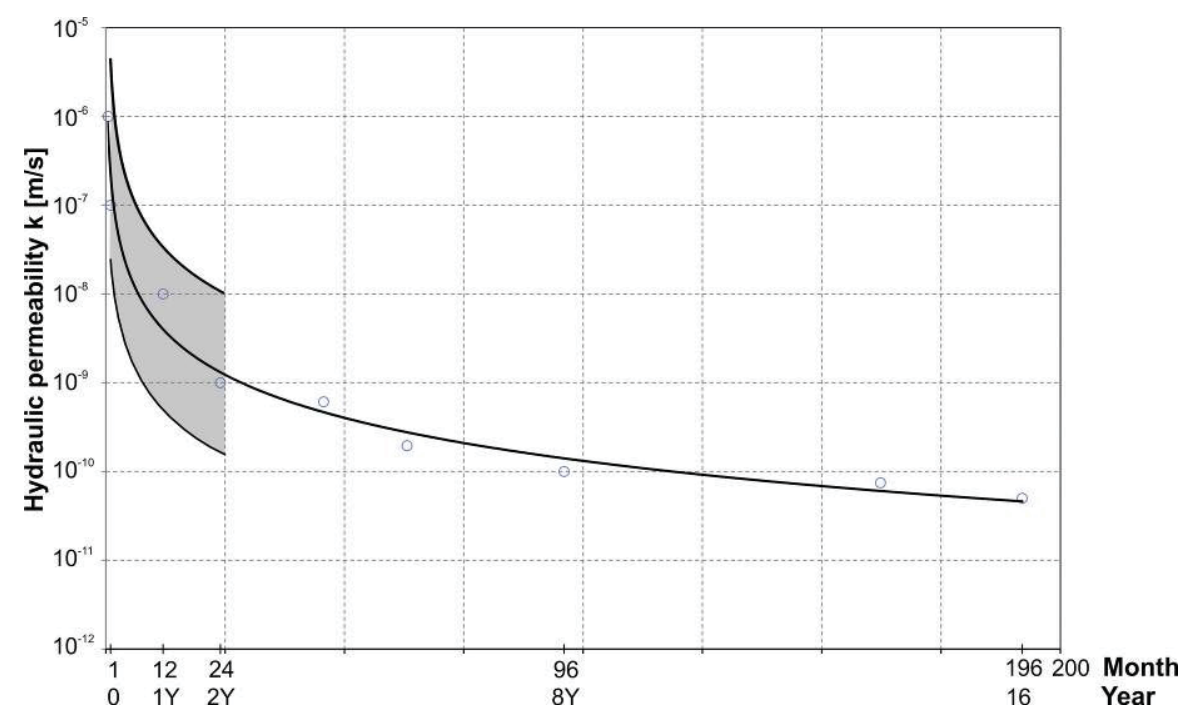

Figure 3. Decrease of hydraulic permeability of pre-treated sludge (25 - $35 \% \mathrm{CaO})$ with time. Scatter of test series within first 2 years and example up to 16 years

Table 1 summarizes the most important geotechnical parameters. The particle size distribution shows "clayey sandy silt" with rather uniform mineralogical contents: Mainly calcite due to the $\mathrm{CaO}$ additives, further quartz and some feldspar and layer silicates. Chemical investigations found some concentration of zinc, copper and lead. The material exhibited liquid consistency and zero to low plasticity. The permeability factor was about $\mathrm{k}=10^{-6} \mathrm{~m} / \mathrm{s}$ at the beginning of the compression (oedometer) test under the load step of $p=30 \mathrm{kN} / \mathrm{m}^{2}$ and decreased to about $\mathrm{k}=10^{-10} \mathrm{~m} / \mathrm{s}$ after 15 years under $p=250 \mathrm{kN} / \mathrm{m}^{2}$. The stress-void ratio diagrams show compression curves similar to natural soils (Fig. 4) but less curved and with strong long-term compression under the maximum load.

Figures 5, 6 show the settlement - time diagrams in semi-logarithmic scale. They illustrate that within the first weeks the settlements were rather small, even under the maximum load step. Then they increased significantly, similar to very soft soils. After one year this intensive consolidation was nearly abruptly followed by creeping comprising mechanical, chemo-physical and anaerobe biological reactions. The latter might be the main reason that creeping of sample $B$ fails to occur linearly with logarithm of time but in a slightly convex curve (Fig. 5).

It is noticeable that the hydraulic permeability decreased most in the first year - corresponding to the settlement curve. Long-term pore clogging is influenced by particle rearrangements, lime reactions and possible biological activities. The sample investigated since the year 2003 was obviously lime-saturated: Repeated hydraulic permeability tests with the oedometer caused mainly in the first phase - some washing out of calcitic particles.

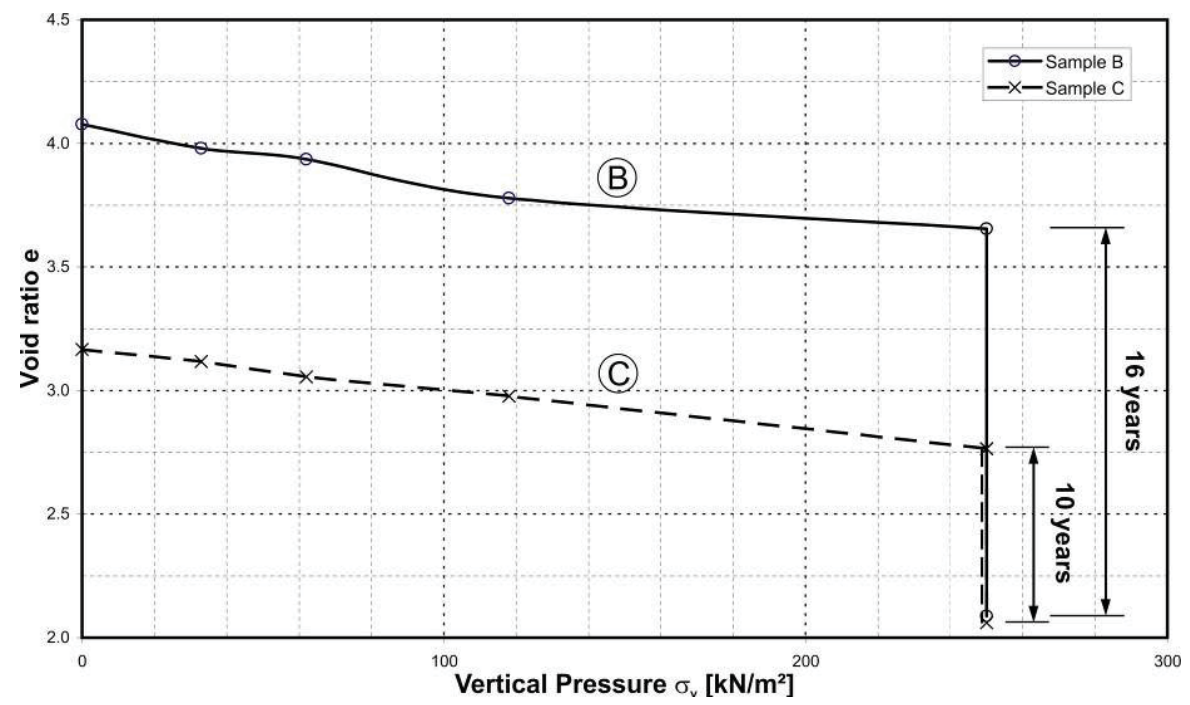

Figure 4. Void ratio - pressure diagram (oedometer tests) for pre-treated sewage sludge (samples B, C). 


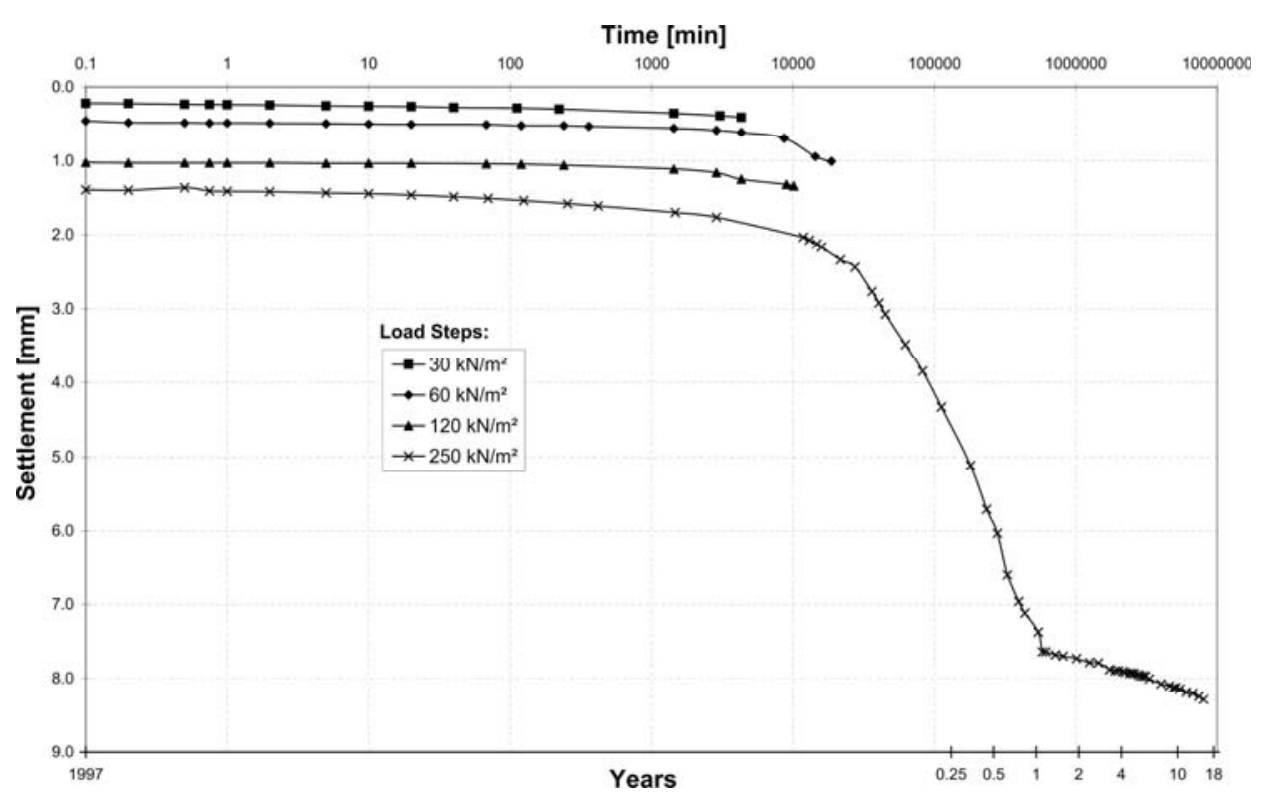

Figure 5. Settlement - log time curves for sample B and increasing load steps (max. 16 years)

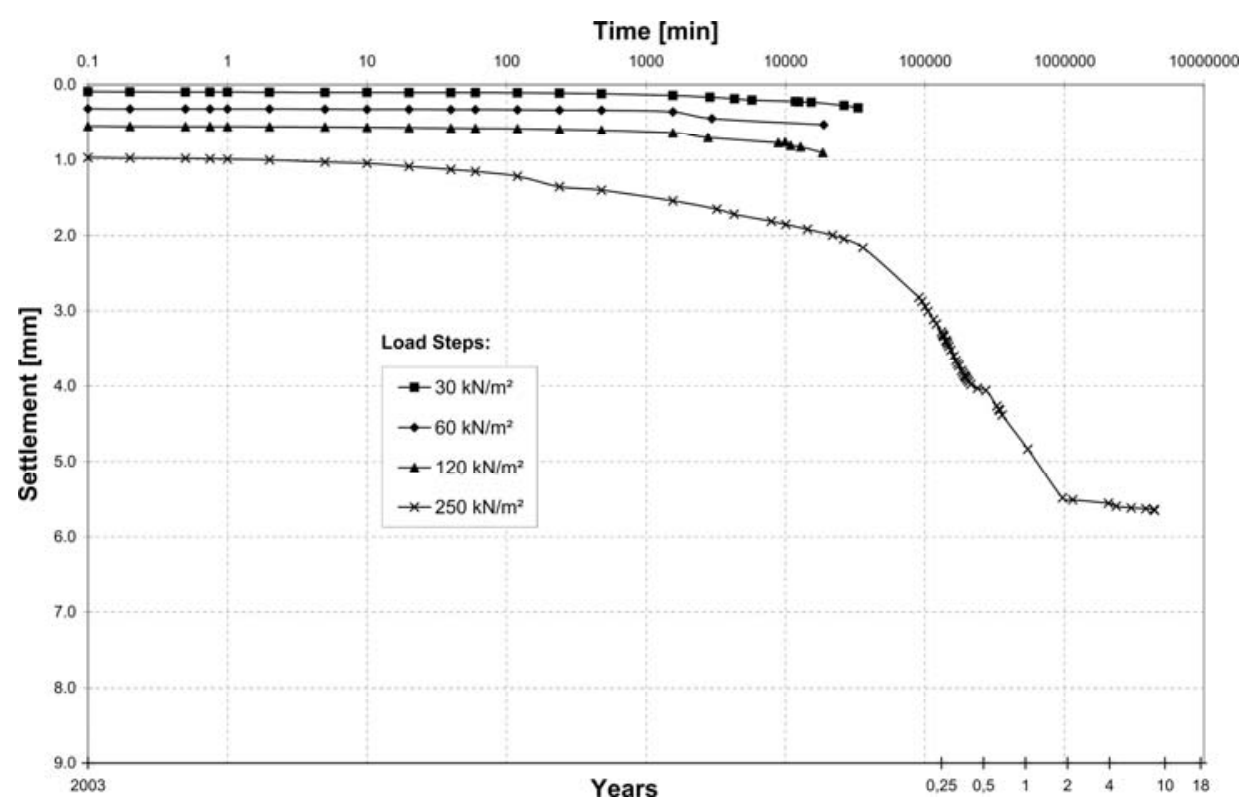

Figure 6. Settlement - log time curves for sample C and increasing load steps (max. 10 years)

Creeping continued until the end of the oedometer tests, i.e. up to 16 years without coming to the end. This clearly indicated a long-term rearrangement of the sludge structure despite the hardening effect of added lime. Similar behaviour could be found for inorganic clayey silt and silty clay stabilized with lime, when cured under water-saturated conditions. However, creeping of such soils faded out at least within ten years. In both cases (sludge and soil) the creeping value (i.e. the gradient of the settlement line) dropped with increasing amount of added lime.

Chemo-physical and anaerobe biological reactions of sludge explain a long-term creeping of sewage sludge, which sometimes differs from natural soil or peat. Though the absolute values are small, the settlement - log $t$ correlation is unlikely a straight line but slightly curved downward - depending on organisms and chemistry (e.g. Fig. 5). Nevertheless, settlements in the oedometer cannot proceed indefinitely.

Unloading of the long-term oedometer tests showed only small swelling. This is due to the high amount of added $\mathrm{CaO}$ and the non-active mineralogical contents.

The hitherto field observations confirmed the results of laboratory and in-situ tests. Primary consolidation of the waste deposit occurred already during the several years lasting landfilling process, and long-term creeping is no problem for the sealing cover. It is smaller than under saturated laboratory conditions because of gradual carbonatisation of the material. 


\section{INFLUENCE OF GROUND IMPROVEMENT ON LONG-TERM SETTLEMENTS}

Between 1972 and 1974 a large highway interchange was constructed on highly compressible heterogeneous ground (Tauernautobahn, Austria). It comprised embankments up to $8 \mathrm{~m}$ height, max. $2.5 \mathrm{~m}$ deep excavations mostly in peat and 8 bridges. The following ground improvement methods were applied (details see Brandl, 2006):

- Deep dynamic compaction/consolidation (heavy tamping),

- Vibroflotation,

- Temporary surcharge loading,

- Local combinations of the previous methods.

Deep dynamic compaction by heavy tamping has been used in Austria and Germany since the 1930s, but was first limited to granular materials, drop weights of about 10 tons and drop heights of about $10 \mathrm{~m}$. Significant development started at this construction site in 1972/73 with 20 to 25 tons falling from heights up to $22.5 \mathrm{~m}$ to improve soft or loose soils respectively and peat to a depth of about $14 \mathrm{~m}$. This required special crawler cranes and in advance fill layers as working platform.

An impact "consolidation" of more or less water saturated (organic) clayey silts and peat was considered "impossible" at that time as being completely contradictory to K. Terzaghi and O.K. Fröhlich's consolidation theory. Fortunately, the owner (Austrian Federal Ministry) could be convinced to allow an increased geotechnical risk in the frame of research and development, and to reduce costs and construction time. Intensive site observations and measurements disclosed that the excessive impacts created from heavy tamping on the soil caused particle rearrangements, local soil liquefaction and steep shear surfaces where vertical drainage up to the ground surface occurred (like artesian water). This behaviour was favoured by (micro)gas bubbles in the soft soil: $100 \%$ water saturation is hardly measured in practice, even in inorganic fine-grained soils below groundwater. This could be observed on numerous construction sites.

The thickness of the highly compressible and heterogeneous layers varied between 3 to $16 \mathrm{~m}$, comprising peat, clayey to sandy silt, silty sand (locally with gravel), and finally sandy gravel. Organic interlayers were found down to $15 \mathrm{~m}$ below original ground. The groundwater level depended strongly on weather and season with a mean value of approximately $2 \mathrm{~m}$ below surface.

Laboratory tests and in-situ measurements provided compression moduli down to $E_{\mathrm{s}}=0.2 \mathrm{MN} / \mathrm{m}^{2}$ and a natural water content up to about $w_{n}=1000 \%$. The saturation degree varied between 75 to nearly $100 \%$, clearly increasing below groundwater table and with depth. The liquid limit lay between $\mathrm{W}_{\mathrm{L}}=20$ to $600 \%$, the plasticity index between $I_{p}=0$ to $250 \%$. These extremely poor ground conditions led to settlements up to about 5 meters already during the construction process. Further details can be obtained from (Brandl, H. 2006).

Oedometer tests on organic soils showed a significant tendency to creeping. According to Figure 7 a creeping coefficient for secondary settlements was derived. The transition from primary to secondary settlement is indicated in Figure 7 by an idealized line, but actually occurred within a longer period. Figure 8 shows that the creeping coefficient varied within a very wide range. Several oedometer tests ran over a period of 20 years and one test up to 42 years (from 1971 to 2013). These long-term investigations have disclosed that secondary and tertiary creep may continue extremely long if the fine-grained soil has a high void ratio and organic components. The mineralogical composition of the fines is influential as well.

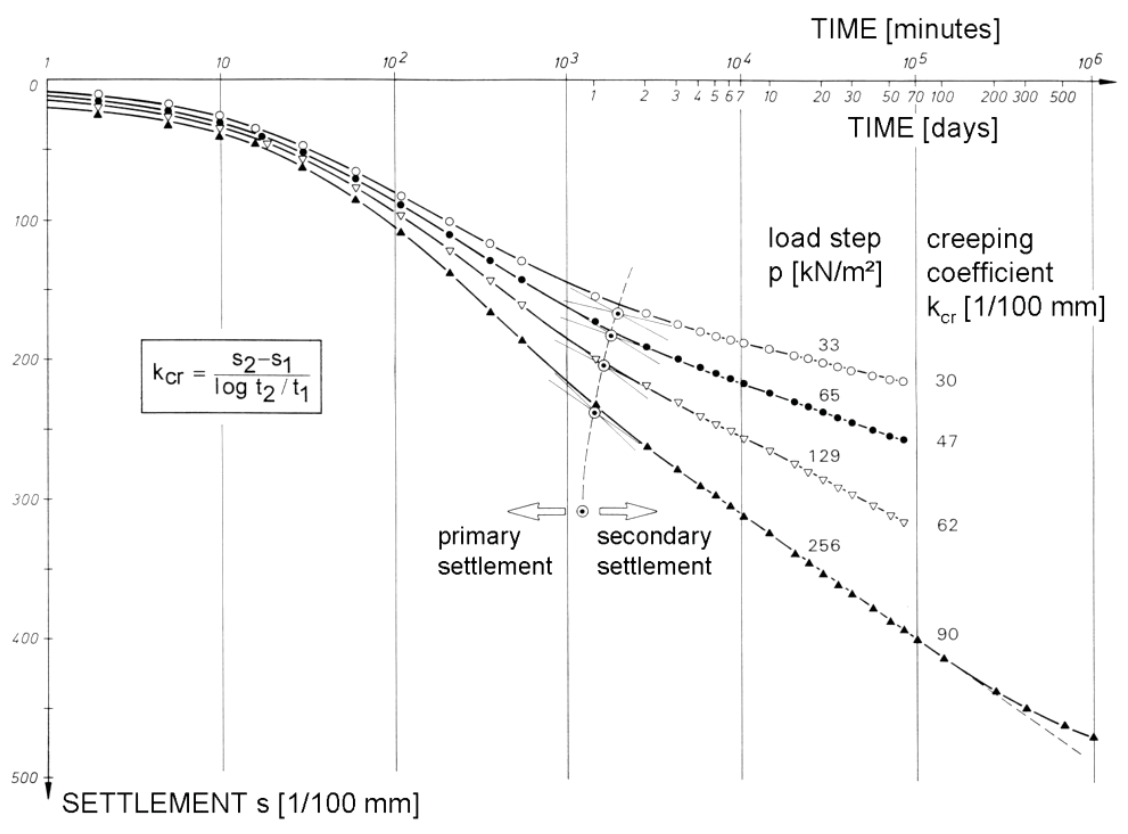

Figure 7. Time-settlement curves of decomposed peat and definition of the creeping coefficient $k_{c r}$ (derived from oedometer tests). 


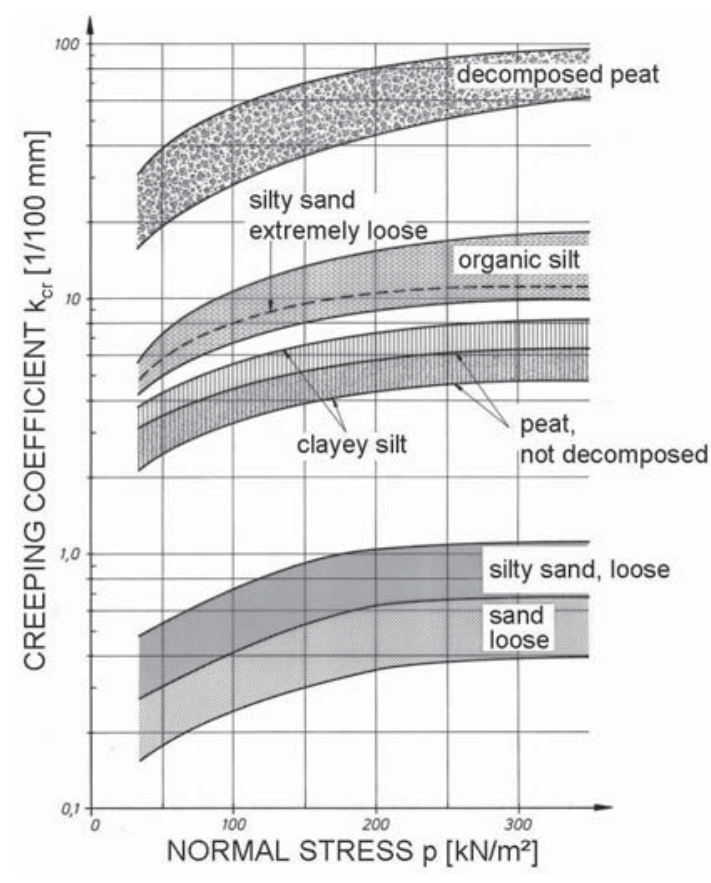

Figure 8. Creeping coefficient $k_{c r}$ for several soils describing secondary settlement (creeping).
The scheme of Figure 9 illustrates the compaction procedure typically applied for the embankments, whereas sections below original ground surface required a partial soil exchange before heavy tamping. Due to the heterogeneous subsoil and varying embankment heights or cut depths respectively the required compaction energy varied in a wide range with a maximum of approximately $\mathrm{E}=2500 \mathrm{tm} / \mathrm{m}^{2}$. Deep compaction control was performed mainly by comparing pressuremeter values before and after heavy tamping. Figure 10 shows an example illustrating the influence depth of heavy tamping and the effects of the embankment weight and time. The influence depth of heavy tamping varied between 8 to $14 \mathrm{~m}$ depending on particular soil properties and energy input.

Figure 11 presents the settlements of an interchange section where seven series of heavy tamping and a temporary surcharge load on the embankment were applied. The final road pavement was installed approximately 16 years after opening of the highway. The secondary settlements within this period did not affect the highway traffic as they occurred rather uniformly.

Figure 12 however, shows this change of the interchange where the maximum settlement occurred after heavy tamping and embankment construction. This required periodical re-levelling despite the construction of a higher level of the pavement already before opening

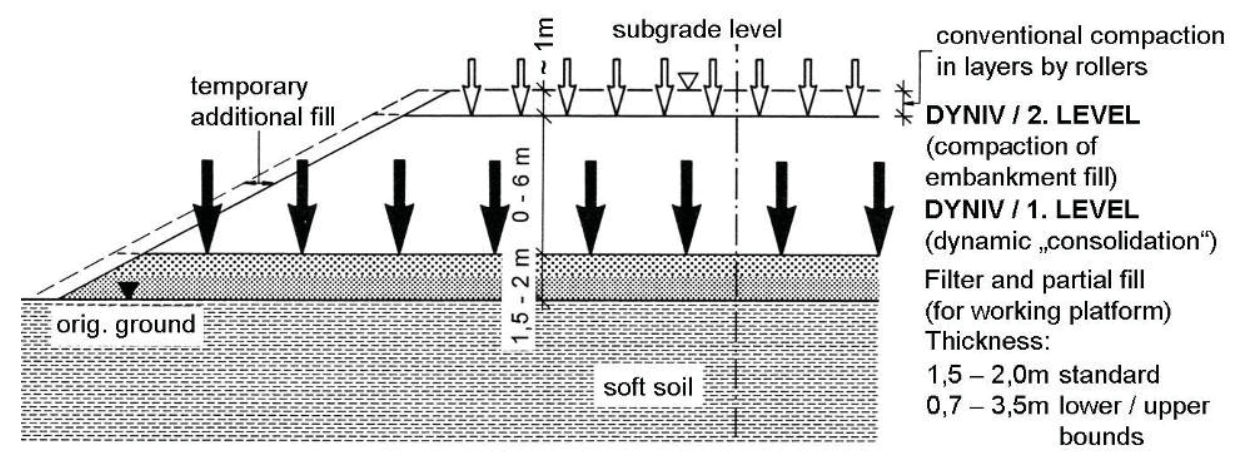

Figure 9. Standard procedure of heavy tamping at a highway interchange performed in the years 1972/1973
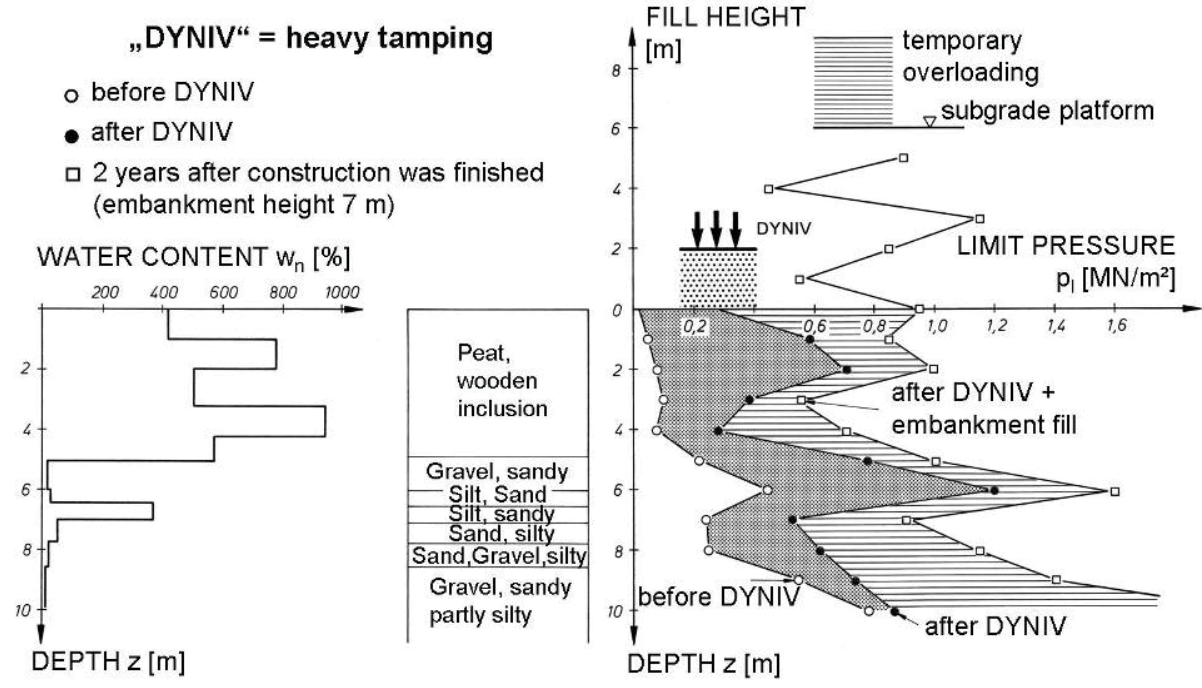

Figure 10. Example of in-situ pressuremeter tests before and after heavy tamping, and two years after the embankment had been constructed 


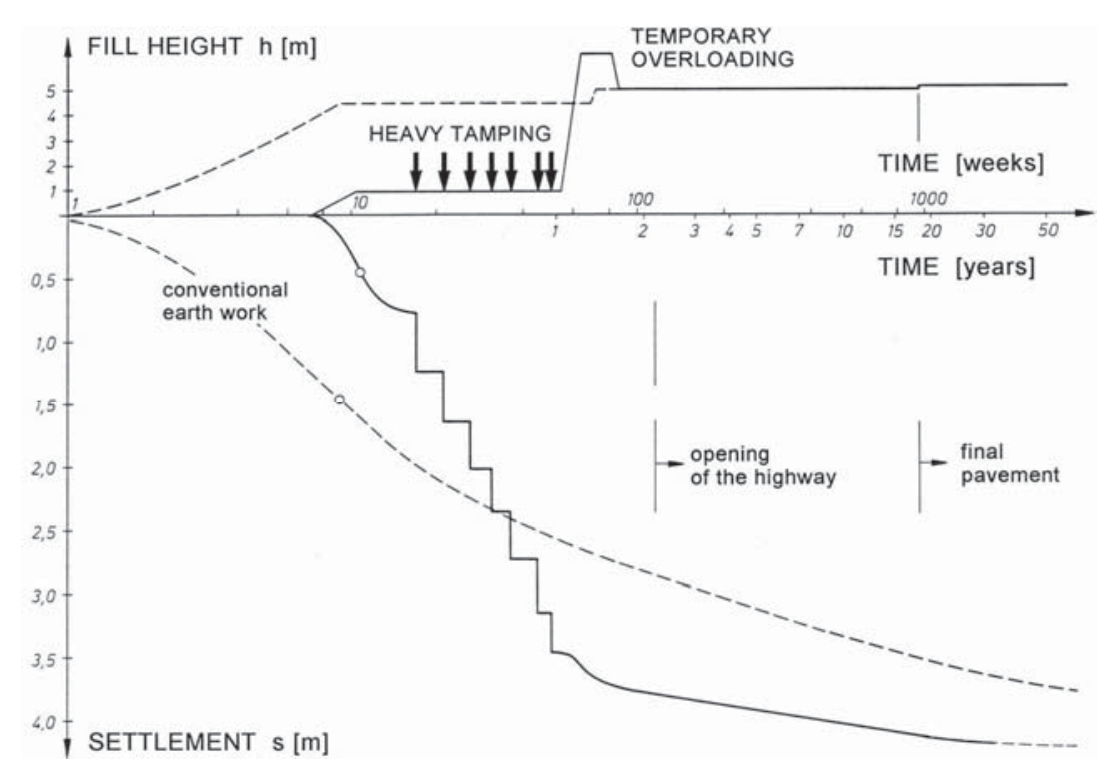

Figure 11.Time-settlement curve of an embankment section. Influence of heavy tamping and temporary surcharge load on the level of the embankment crown

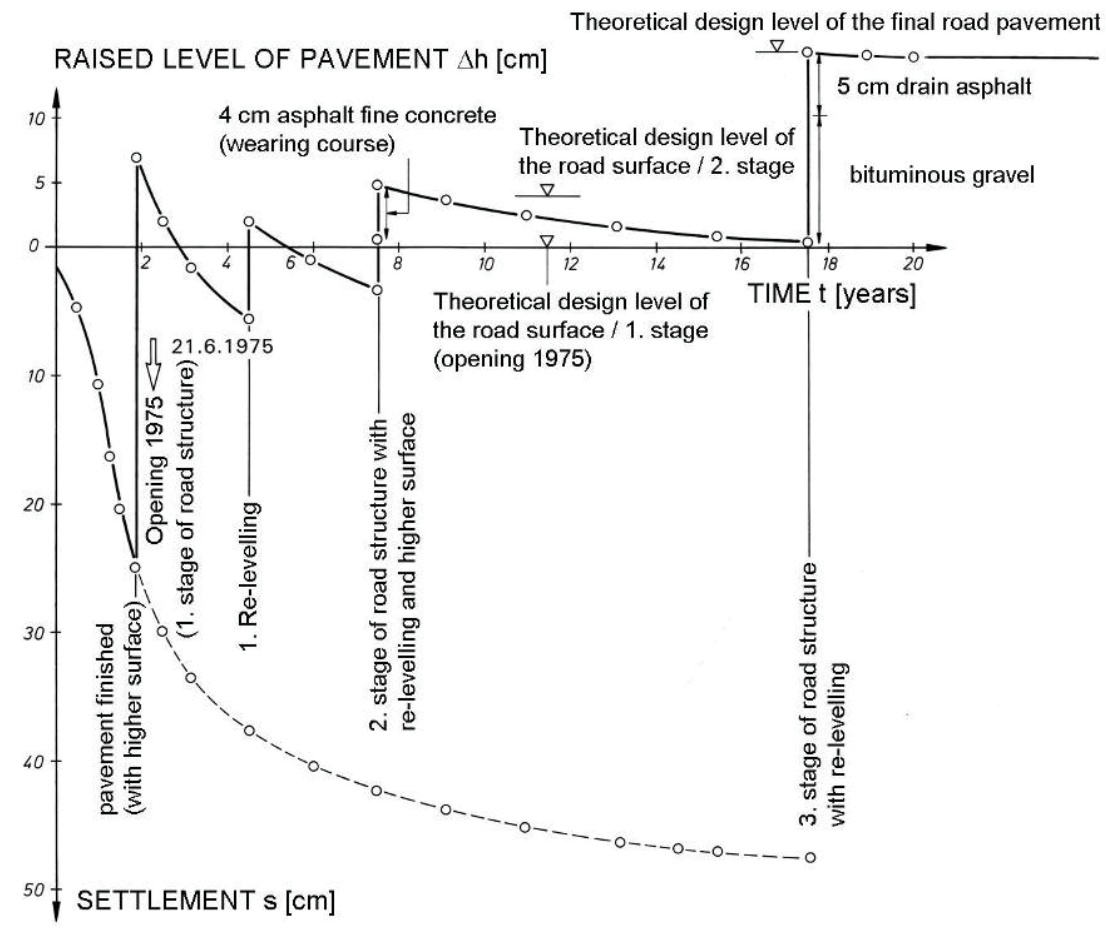

Figure 12. Time-displacement curves (related to the design level of the road surface) involving periodical re-levelling and installation of additional surfacing layers to achieve sufficient driving comfort (Section 10).

Design speed for car traffic: $v=150 \mathrm{~km} / \mathrm{h}$

for the traffic (compensation for expected long-term settlements). But only the first measure (in 1977) was an additional one; the other re-levelling procedures were performed in connection with the installation of the final layers of the road pavement according to the original design (remediation of wearing courses, placing drain asphalt etc.).
The long-term behaviour of this highway interchange may be summarized as follows:

The project was a pioneer work regarding heavy tamping and piled embankments. Previous experience with weights of 20 to 25 tons dropping from heights up to $22.5 \mathrm{~m}$ did not yet exist worldwide, and the fine-grained, organic ground with a water content up to $1000 \%$ was 
another challenge. Despite these unfavourable conditions a satisfactory long-term behaviour of the entire interchange could be achieved. The maximum total settlement (including anticipated deformations by heavy tamping and temporary surcharge loading of the embankments) was approximately $5 \mathrm{~m}$ which occurred mainly during the construction period. Local re-levelling of the primary (provisional) road surface on the basis of the contractor's quality guarantee was necessary only once, namely 2.5 years after opening of the highway. This measure was limited to some sections of heavy tamping only.

Long-term creeping after highway opening varied between 5 to $20 \mathrm{~cm}$ and occurred rather uniformly. The piled embankments resting on stone columns with compound body cover (geosynthetics, cement stabilization, crushed rock) behaved even better than the sections with heavy tamping. However, the ground properties were somewhat better there. Temporary surcharge loading of the embankment proved to be also very successful, especially in connection with previous heavy tamping.

According to Austrian highway guidelines and codes the definite surfacing of the road pavement was placed approximately 4.5 years after opening of the highway $\left(2^{\text {nd }}\right.$ stage of road structure). The final surfacing, 16 years after opening, involved the placement of a new road structure with a more traffic resistant wearing course above the old structure. This remediation was required primarily because of the long-term degradation of the road pavement (deep traffic ruttings etc.) due to heavy traffic. The influence of differential settlements was negligible. However, both road surfacing measures (4.5 and 16 years after highway opening) involved also a re-levelling.

To sum up, the long-term behaviour of this highway interchange has been very satisfactory for about 40 years now. The design speed of $v=150 \mathrm{~km} / \mathrm{h}$ could be maintained during the entire period. The settlement prognoses based on laboratory and field tests, on analytical calculations, on empirical parameters and experience have been in good accordance with the measured values. Long-term creeping is still going on but negligible for traffic comfort and maintenance.

Comprehensive field observations have disclosed how method and quality of deep soil improvement influence primary consolidation and creeping of soils. Consequently, if a ground tends to strong creeping (observed in laboratory tests), soil improvement technologies have to be properly selected or adapted, resp. For instance, vertical drains accelerate only pore water dissipation during primary consolidation, but fail to improve creeping behaviour.

Prediction of primary and secondary settlements was important for constructing a temporarily higher level of sub grade and asphalt surface of the highway junction running on the embankments on highly compressible ground ("compensation fill").
Several comparative tests showed that Atterberg limits or activity index, resp. are insufficient as a criterion for creep assessment, because soil creep depends on numerous factors: Grain size distribution, mineral optical composition, moisture content, permeability, density, fabrics structural strength, viscosity, and external factors lead to an extremely complex process.

\section{CONCLUSIONS}

All three-phase systems containing particles, liquids and gas exhibit creep under compressive stress. Secondary creeping of clayey soft soils mostly occurs linear with the logarithm of time. However, temporary increase may also be observed, indicating a discontinuous nature of internal deformations due to accelerated rearrangement in the fabric - mainly in soils with peaty components. A micro-mechanical explanation is ductile sliding between mineral crystals followed by repeated structural ruptures.

Long-term oedometer tests on soils and pre-treated sewage sludge have revealed several similarities between natural and artificial fine materials of high compressibility. The tests ran up to 42 years and showed a gradual transition from secondary to tertiary creep for organic clayey silts after about one year. During tertiary creep the gradient, plotted on semilogarithmic scale, gradually decreased. This could be found also for inorganic clays under site conditions, where the gradient may eventually approach zero.

In pre-treated sewage sludge the transition from primary to secondary consolidation is more significant than in soils. No fading out tertiary creep could be observed in the semi-log diagrams of oedometer tests. This could be explained by chemo-physical and anaerobe biological long-term reactions in this material.

Several other comparative tests have confirmed that organic soils show pronounced secondary/tertiary creeping, and that creeping also depends on the mineralogical composition and the arrangement (microscopic structure) of the fines, and not only on grain size distribution, initial porosity, consistency, etc. Consequently, prognoses of creeping derived from oedometer tests (with site-specific data) are still more reliable than those from exclusively numerical modelling (with data from the literature) or uncertain correlations. Additionally, investigations based on geochemistry and electron microscope analyses might be helpful.

Finally, the long-term tests have disclosed, that $\mathrm{K}$. Buisman's creep theory is widely consistent, although tertiary creep has to be added and settlements cannot run indefinitely. The application of oedometric results for the prediction of creeping in the field has to consider lateral displacements and shearing and possible measures of ground improvement. Three-dimensional field conditions accelerate creeping in relation to one dimensional oedometer tests (with stiff side walls). 


\section{REFERENCES}

[1] Brandl, H. (2006). "Ground improvement and earthwork innovations for transportation infrastructure".Active Geotechnical Design in Infrastructure Development. XIII Danube-European Conference on Geotechnical Eng., CIP-Ljubljana, Vol. 1, 217-232.

[2] Buisman, A.S.K. (1936). "Results of long duration settlement observations". Proceedings of the 1st International Conference of the ISSMFE

SUMMARY

\section{CREEPING (SECONDARYITERTIARY SETTLEMENTS) OF HIGHLY COMPRESSIBLE SOILS AND SLUDGE}

\section{H. BRANDL}

The paper focuses on long-term oedometer tests lasting up to 42 years and performed on silty sand, (organic) clayey silt, peat and (pre-treated) sewage sludge. Secondary consolidation (creep) could be observed in all cases, lasting over many years and occurring widely linear with the logarithm of time. This long-term phase is followed by tertiary creep with a long lasting fading out period. In addition to the laboratory tests results of comprehensive field observations are summarized, showing the influence of ground improvement on the creeping behaviour of very soft finegrained soils (partly organic). The data were collected from a highway junction on highly compressible, heterogeneous ground (with natural water content up to 100\%), constructed between 1972 and 1974, and monitored since.

Key words: long-term settlements, creeping, highly compressible soils, oedometer tests, heavy tamping, deep soil improvement, sludge
(International Society for Soil Mechanics and Foundation Engineering), Cambridge, Vol. 1, 103106.

[3] Terzaghi, K. and Fröhlich, O.K. (1936). „Theorie der Setzung von Tonschichten“. Franz Deuticke, Leipzig - Wien.

[4] Havel, F. (2004). "Creep in soft soils“. Doc. Thesis. Norwegian Univ. of Science and Technology, Trondheim.
REZIME

\section{TEČENJA (SEKUNDARNA/TERCIJALNA SLEGANJA) VEOMA STIŠLJIVOG TLA I TALOGA}

\section{H. BRANDL}

Ovaj rad je usmeren na dugotrajna edometarska ispitivanja koja su trajala 42 godine i izvedena su na prašinastom pesku, (organskoj) glinovitoj prašini, tresetu, i (pre obrade) kanalizacionom talogu. Sekundarna konsolidacija (tečenje/puzanje) mogla je da bude uočena u svim slučajevima i trajala je mnogo godina i ispoljavala se, uglavnom, kao linearno zavisna od logaritma vremena. Ovu dugotrajnu fazu prati tercijarno tečenje sa dugotrajnim periodom vremena do konačnog nestajanja. Osim laboratorijskih opita, sumirani su rezultati sveobuhvatnih terenskih ispitivanja i oni pokazuju uticaj poboljšanja tla na tečenje vrlo mekog sitnozrnog tla (delimično organskog). Ovi podaci su prikupljeni na raskrsnici autoputa na veoma stišljivom heterogenom zemljištu (sa prirodnim sadržajem vode do 100\%) koja je izgrađena između 1972 i 1974 i od tada je osmatrana.

Ključne reči: dugotrajna sleganja, tečenje (puzanje), jako stišljivo tlo, edometarski opiti, dinamičko zbijanje, poboljšanje dubljih slojeva tla, talog 